\title{
Evaluation of Synthetic Outlet Runoff Assessment Models
}

\section{${ }^{1}$ ARASH ADIB; ${ }^{2}$ MEYSAM SALARIJAZI; ${ }^{3}$ KHOSRO NAJAFPOUR}

\author{
${ }^{1}$ Shahid Chamran University, Engineering Faculty, Civil Engineering Department \\ ${ }^{2}$ Shahid Chamran University, Water Science Engineering Faculty, Hydrology and Water Resources Department \\ ${ }^{3}$ Islamic Azad University of Shooshtar, Civil Engineering Department
}

\begin{abstract}
Quantitative understanding and prediction of the processes of runoff generation and its transmission to the outlet represent one of the most basic and challenging areas of hydrology. Traditional techniques for design flood estimation use historical rainfall-runoff data for unit hydrograph (UH) derivation. Such techniques have been widely applied for the estimation of design flood hydrograph at the sites of gauged catchment. For ungauged catchments, unit hydrograph may be derived using synthetic SCS and Snyder unit hydrograph models. This research has been carried out for comparison of the correctness of SCS and Snyder unit hydrograph models in determination of the shape and dimensions of outlet runoff hydrograph in Kasilian watershed. This watershed has $67.5 \mathrm{~km}^{2}$ area and it locates in Mazandaran province of Iran. The runoff hydrographs computed by the SCS and Snyder models were compared with observed hydrographs by using of three error functions, viz. 1-model efficiency (EFF), 2-percentage error in peak (PEP), and 3-percentage error in time to peak (PETP). The results reveal the accuracy and applicability of these synthetic models for derivation of runoff hydrograph. @ JASEM
\end{abstract}

Estimation of runoff response from ungauged catchments has been an important subject of research for planning, development and operation of various water resources projects. Hydrograph is a curve that shows the variations of runoff discharge rate with respect to time and on the other hand, the dimensions of hydrograph of outlet discharge rate, shows quantitative and final responses of watershed to inlet rainfall. Therefore, knowledge of the relationship between rainfall and runoff is one of the important issues in the hydrology. One of the common methods in flood estimation is the use of unit hydrograph which not only is applied for peak flow estimation, but also for creation of complicated flood hydrographs. Unit hydrograph and flood hydrograph which is obtained from rainfall and discharge rate of a watershed is used for that watershed and river only. The conventional techniques of derivation of unit hydrograph (UH) require historical rainfall-runoff data. Due to obvious reasons, adequate runoff data are, generally not available for many of the small and medium size catchments. Indirect inferences through regionalization are sought for such types of the ungauged catchments. Many times this task of regionalization becomes very tedious and in certain cases even impossible. For other points of river or watersheds having similar characteristics, artificial hydrograph method is used. Among common methods for artificial unit hydrographs, SCS and Snyder models can be cited. Ghioto (1991) compared SCS, Snyder and Santa barba hydrographs and showed that in big watersheds, SCS model has better estimation. Bonta and Roa (1991) applied four statistical distributions (Gamma, Beta, Weibul and $\mathrm{K}^{2}$ ) and three artificial unit hydrographs (Snyder, SCS and Gray) in two sub-watersheds with area of 114 and $350 \mathrm{~km}^{2}$ in India. Among methods of estimation of unit artificial hydrographs, the percentage of relative error in time to peak and peak discharge rate of hydrographs obtained from SCS method had 20 and 3\% and standard error of $2.95 \%$ which shows that this method is suitable for watersheds of without data. The Soil Conservation Service Curve Number (SCS-CN) method (SCS, 1993) is commonly used for estimating the depth of surface runoff in a watershed for a given rainfall event. It has recently been renamed as Natural Resource Conservation Service Curve Number (CN) method. The method is simple and useful for ungauged watersheds and accounts for four major runoff producing watershed characteristics, viz., soil type, land use/treatment, surface condition and antecedent moisture conditions (Ponce and Hawkins, 1996). The method has been a topic of much discussion in hydrologic literature for the last three decades (Michel et al., 2005), (Schneider and McCuen, 2005), (Mishra et al., 2006) and (Sahu et al., 2007). Despite several modifications of the SCS$\mathrm{CN}$ method have been suggested and reported in literature, a need for further improvement of the method has been experienced (Ponce and Hawkins, 1996) and (Mishra and Singh, 2002). Michel et al. (2005) pointed out several inconsistencies in the soil moisture accounting (SMA) procedure of the SCS$\mathrm{CN}$ method and proposed a more rational procedure. Their modification, however, does not contain an expression for determination of initial soil moisture store level $\left(V_{0}\right)$, a crucial parameter. Sahu et al. (2007) provided an expression for $V_{0}$ and modified the model. In the present study, both these modifications along with the original SCS-CN model and its other variants are compared with each other for their performance on a large set of data derived from 76 U.S. agricultural watersheds. 


\section{MATERIALS AND METHODS}

Case Study: In addition to geomorphologic data, the obtained data from several rain falls- run offs events were recorded in the Kasilian watershed. This watershed is a small part of Caspian Sea watershed is considered as one of six major watersheds in Iran. The Kasilian watershed locates between latitude $35^{\circ} 58^{\prime} 45^{\prime}$ to $36^{\circ} 07^{\prime} 4^{\prime}$ north and between longitude $53^{\circ} 10^{\prime}$ $30^{\prime}$ to $53^{\circ} 17^{\prime} 30^{\prime}$ east. The Tajor and Bozla River watersheds locate in the north and south of the Kasilian watershed, respectively.

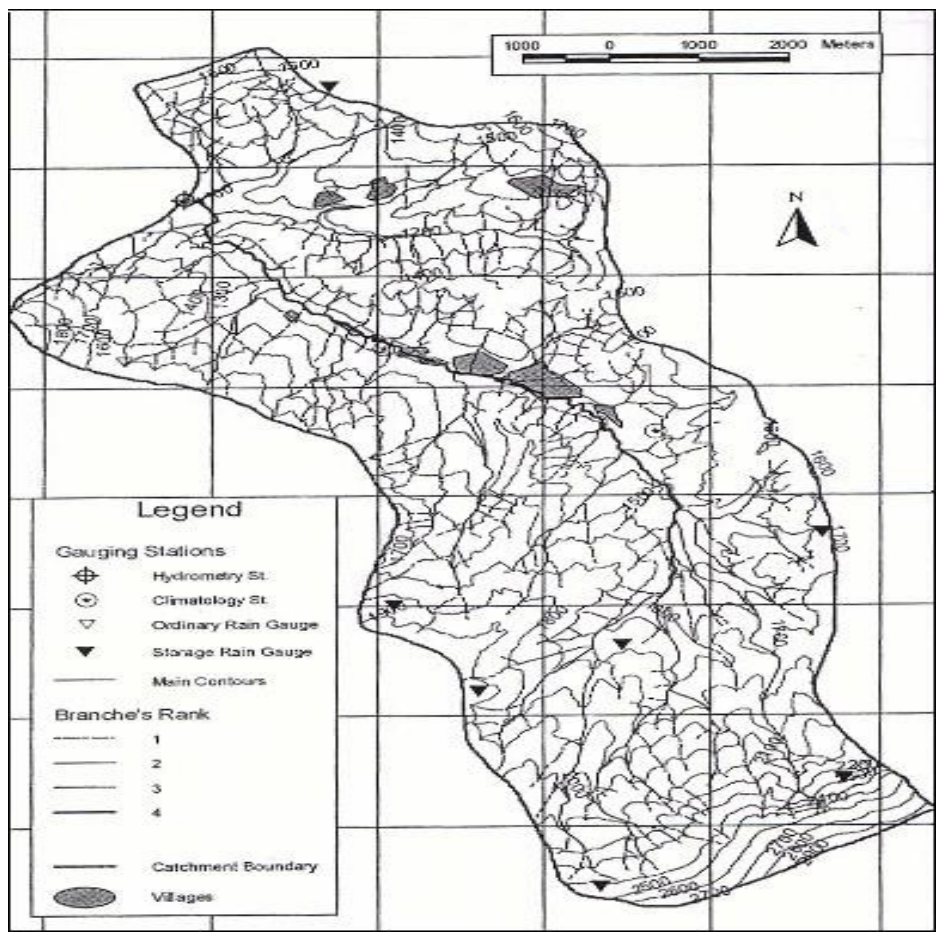

Fig.1. Map of the Kasilian watershed

In addition, the Tajan and Talar River watersheds locate in the east and west of the Kasilian watershed, respectively. Kasilian watershed has an area of $67.5 \mathrm{~km}^{2}$ and is 1100 to $2900 \mathrm{~m}$ above sea level. A hydrometric station was constructed at the outlet of watershed, in Valikben village. In this research, a 29-year-time series of hydrometric data from October 1970 to October 1999 has been employed. The Kasilian watershed has three ordinary rainfall stations. The Sangdeh rainfall station is one of these stations that locate in the center of the Kasilian watershed. The data of this station are more accurate than data of other stations. The Kasilian River is the main river of watershed and its length is $16.2 \mathrm{Km}$. Map of the Kasilian watershed is shown in Figure 1.

Methods: Because of optimization ability and practicality of HEC-HMS soft ware this program is used for simulation. HEC-HMS (Hydrologic Modeling System) is a computer program that was developed by the Hydrologic Engineering Center (HEC) of the US Army Corps of Engineers. This program simulates rainfall-runoff and routing processes, both natural and controlled. HEC-HMS is replacement HEC-1 program. HEC-HMS improves upon the capabilities of HEC-1 and provides additional capabilities for distributed modeling and continuous simulation.

Basic Concepts and Equations of SCS UH: The SCS $\mathrm{UH}$ is a dimensionless, single-peaked UH. This dimensionless $\mathrm{UH}$, expresses the UH discharge, $Q_{t}$, as a ratio to the $\mathrm{UH}$ peak discharge, $Q_{p}$, for any time $t$, a fraction of $T_{p}$, the time to UH peak. The SCS method suggests below relation:

$Q_{p}=\mathrm{CA} / T_{p}$

Where: $A$ : Watershed area; $C$ : Conversion constant (2.08 in SI and 484 in English system) 
Evaluation of Synthetic Outlet.....

The time of peak (also known as the time of rise) is related to the duration of the unit of excess precipitation as:

$T_{p}=\Delta t / 2+t_{l a g}$

Where: $\Delta t$ : the excess precipitation duration; $t_{\text {lag }}$ : the lag time, defined as the time difference between the center of mass of rainfall excess and the peak of the UH. [Note that for adequate definition of the ordinates on the rising limb of the SCS UH, a computational interval, $\Delta t$, that is less than $29 \%$ of $t_{\text {lag }}$ must be used (USACE, 1998). When the lag time is specified, the program solves Equations to find the time of UH peak and UH peak. With $Q p$ and $T_{p}$ known, the UH can be found from the dimensionless form.

The lag time of SCS UH can be estimated via calibration, for gauged watersheds.

For ungauged watersheds, the SCS suggests that the lag time of $\mathrm{UH}$ may be related to time of concentration, $t_{c}$, as:

$t_{\text {lag }}=0.6$

In 1938, Snyder published a description of a parametric UH that he had developed for analysis of ungauged watersheds in the Appalachian Highlands in the US. More importantly, he provided relationships for estimating the UH parameters from watershed characteristics. The program includes an implementation of the Snyder UH.

For his work, Snyder selected the lag time, peak flow, and base time as the critical characteristics of a UH. He defined a standard UH as one whose rainfall duration, $t_{r}$, is related to the lag time, $T_{\text {lag }}$, by:

$$
T_{\text {lag }}=5.5 t_{r}
$$

Thus, if the duration is specified, the lag time (and hence the time of UH peak) of Snyder's standard UH can be found. If the duration of the desired $\mathrm{UH}$ for the watershed of interest is significantly different from that specified by Equation, the following relationship can be used to define the relationship of UH peak time and UH duration:

$T_{\text {lag-R }}=T_{\text {lag }}-\frac{t_{r}-t_{R}}{4}(5)$

Where: $t_{R}$ : Duration of desired $\mathrm{UH} ; t_{l a g-R}$ : Lag time of desired UH
For the standard case, Snyder discovered that UH lag time and peak per unit of excess precipitation per unit area of the watershed were related by:

$$
\frac{Q_{p}}{A}=C\left(\frac{C_{p}}{T_{l a g}}\right)
$$

Where: $Q_{p}$ : Peak of standard UH; $C_{p}: \mathrm{UH}$ peaking coefficient; $C$ : Conversion constant $(2.75$ for SI or 640 for English system). For other durations, the UH peak, $Q_{p R}$, is defined as:

$$
\frac{Q_{p R}}{A}=C\left(\frac{C_{p}}{T_{\text {lag-R }}}\right)
$$

Snyder's UH model requires specifying the standard lag time, $T_{\text {lag }}$, and the coefficient, $C_{p}$. The program sets $T_{l a g-R}$ equal the specified time interval, and solves Equation to find the lag time of the required $\mathrm{UH}$ and $\mathrm{UH}$ peak.

\section{RESULTS AND DISCUSSION}

In this research, it is assume that infiltration rate is constant. For comparison results of different models, 13 storm events were considered. The parameter of the SCS UH model ( lag time $t_{\text {lag }}$ ) and the Snyder UH model (standard lag time and peak coefficient, $T_{\text {lag }}$ and $C_{p}$ ) were calculated by using of the historical data of all nine rainfall-runoff events. Lag time is from 160 to $468 \mathrm{~min}$ in SCS UH model. Standard lag time is from 2 to $8 \mathrm{hr}$ and peak coefficient is from 0.21 to 0.79 in Snyder UH model. The calculated values of lag time, standard lag time, and peak coefficient parameter as well as their geometric mean are shown in table 1 for 9 storm events.

Table1. Parameters of the SCS and Snyder UH models for

\begin{tabular}{|c|c|c|c|}
\hline \multirow{3}{*}{ Event number } & \multicolumn{2}{|c|}{ Snyder } & SCS \\
\cline { 2 - 4 } & $C_{p}$ & $T_{\text {lag }}(\mathrm{hr})$ & $t_{\text {lag }}(\mathrm{min})$ \\
\hline 1 & 0.79 & 5.95 & 325 \\
\hline 2 & 0.78 & 4.72 & 263 \\
\hline 3 & 0.21 & 2.95 & 349 \\
\hline 4 & 0.5 & 3.68 & 292 \\
\hline 5 & 0.66 & 7.99 & 468 \\
\hline 6 & 0.55 & 3 & 208 \\
\hline 7 & 0.64 & 6.61 & 374 \\
\hline 8 & 0.42 & 2.01 & 160 \\
\hline 9 & 0.55 & 3.23 & 204 \\
\hline $\begin{array}{c}\text { Geometric } \\
\text { mean }\end{array}$ & 0.53 & 4.08 & 279 \\
\hline
\end{tabular}


Storm events 1-9 were selected for calibration, whereas the remaining four storm events were selected for validation of the SCS and Snyder UH models. The calibrated parameters of the SCS and Snyder UH models were estimated by taking the geometric mean of the parameters. The values of the calibrated parameters for the SCS and Snyder UH models were $t_{\text {lag }}=279 \mathrm{~min}$ and $T_{\text {lag }}=4.08 \mathrm{hr}$, and $C_{p}=0.53$ respectively. These parameter values were applied in the last four events to derive the UH. The convolution of the $\mathrm{UH}$ with the excess rainfall hyetograph produces the computed runoff hydrograph.By attention to calibrated values of parameters of SCS and Snyder UH Models, the outlet runoff hydrographs computed by using of the SCS and Snyder UH Models in last four events have been compared with the observed outlet runoff hydrographs. For this purpose, it is employing some of the error functions. Applied error functions in this research are:

(a) Model efficiency, (b) Percentage error in peak and

(c) Percentage error in time to peak, given in:

$$
E F F=\left(1-\frac{\sum_{i=1}^{m}\left(Q_{o i}-Q_{c i}\right)^{2}}{\sum_{i=1}^{m}\left(Q_{o i}-\bar{Q}_{o}\right)^{2}}\right) \times 100
$$

Where: EFF : Model efficiency (\%); $Q_{o i}:$ ith ordinate of the observed discharge ; $\left(\mathrm{m}^{3} / \mathrm{s}\right) ; \bar{Q}_{o}$ : Average of the ordinates of observed discharge $\left(m^{3} / s\right) ; \quad Q_{c i}$ : $\quad$ Computed discharge $\left(m^{3} / s\right) ; m$ : Number of ordinates

$P E P=\left(1-\frac{Q_{p c}}{Q_{p o}}\right) \times 100$

Where: $P E P$ : Percentage error in peak $(\%) ; Q_{p o}$ : Observed peak discharge $\left(\mathrm{m}^{3} / s\right) ; Q_{p c}$ : Computed peak discharge $\left(\mathrm{m}^{3} / \mathrm{s}\right)$

$P E T P=\left(1-\frac{T_{p c}}{T_{p o}}\right) \times 100$

Where: PETP : Percentage error in time to peak $(\%)$ $; T_{p o}$ : Time to peak of observed discharge (hr) $; T_{p c}$ : Time to peak of computed discharge (hr)

Runoff hydrographs computed by using of the SCS and Snyder UH models are compared with the observed Runoff hydrographs for four rainfall-runoff events. Error functions are evaluated for the SCS and Snyder UH Models by using of observed Runoff hydrographs. The parameters of SCS and Snyder UH models were calculated by using of geometric mean of nine primary rainfall- runoff events.
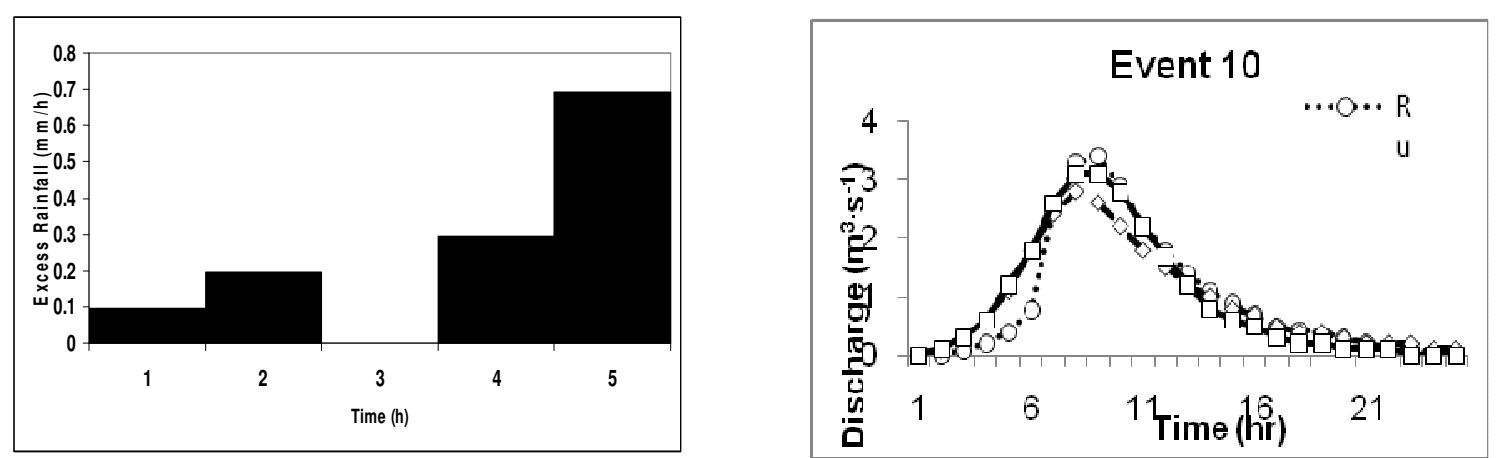

Fig.2. Excess rainfall hyetograph and observed runoff hydrographs and runoff hydrographs computed by the SCS and Snyder UH models for event 10

Runoff hydrographs computed by the SCS and Snyder UH models are compared with the observed Runoff hydrographs as shown in Figs. 2, 3, 4 and 5 for events $10,11,12$ and 13 .

The values of error functions of 4 storm events are shown in figure 6 for different models. The mean of EFF of SCS and Snyder UH models is 39.5, 49.5 percent respectively, while the mean of PEP of SCS and Snyder UH models is $-7.5,7$ percent respectively and that of PETP of SCS and Snyder UH models is $7.75,17.25$ percent respectively. The range of model efficiency is from -37 to 91 percent for SCS UH model and it is from 10 to 87 percent for Snyder UH models. The range of percentage error in peak (PEP) is from -54to 13 percent for SCS UH model and it is from -30 to 25 percent for Snyder UH models. The 
range of percentage error in time to peak (PETP) is from -14 to 20 percent for SCS UH model and it is from 0 to 30 percent for Snyder UH model.

In this research, synthetic model is considered for evaluation of outlet runoff hydrograph. HEC-HMS software is applied for simulation. By assuming an constant value of effective rainfall throughout the duration of rainfall and a uniform spatial pattern in the watershed, the SCS and Snyder UH models has been applied for estimation of the runoff hydrographs in a watershed of northern part of Iran.
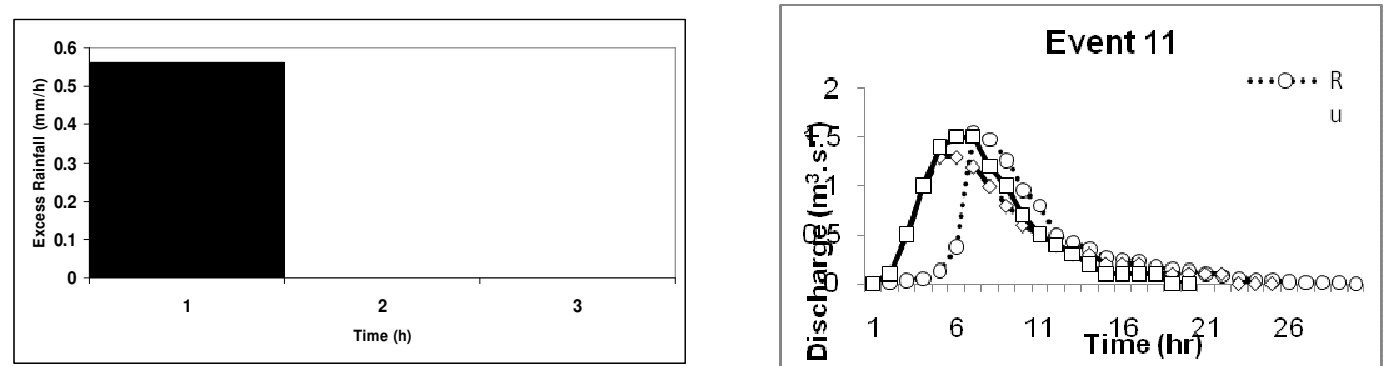

Fig.3. Excess rainfall hyetograph and observed runoff hydrographs and runoff hydrographs computed by the SCS and Snyder UH models for event 11
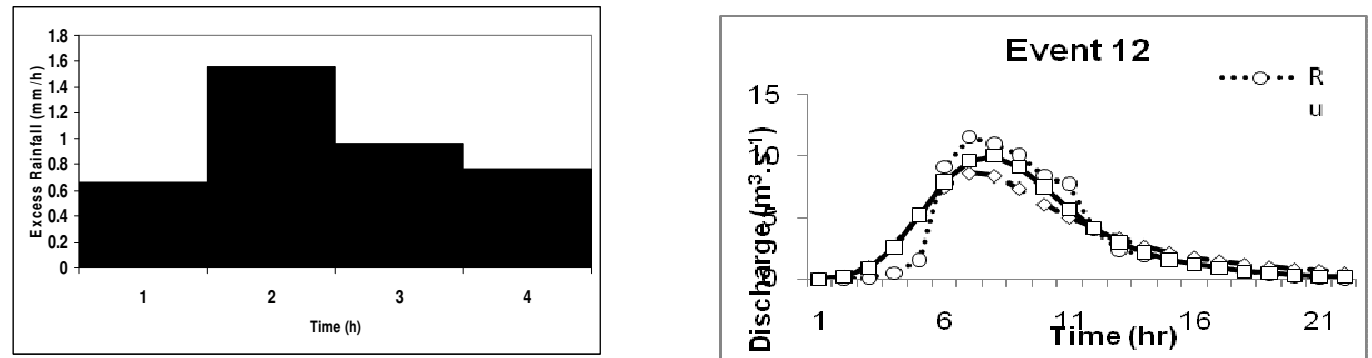

Fig.4. Excess rainfall hyetograph and observed runoff hydrographs and runoff hydrographs computed by the SCS and Snyder UH models for event 12
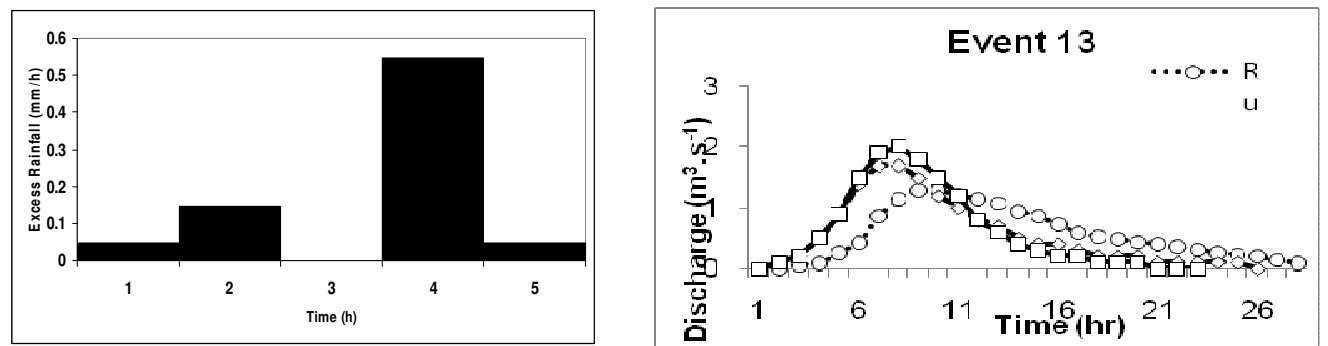

Fig.5. Excess rainfall hyetograph and observed runoff hydrographs and runoff hydrographs computed by the SCS and Snyder UH models for event 13

Three error functions were applied to comparison of calculated (simulated) outlet runoff hydrographs and observed runoff hydrographs. Investigation of Model efficiency, Percentage error in peak and Percentage error in time to peak reveals wide range of them. With comparison between the runoff hydrographs estimated by the SCS and Snyder UH models and the observed runoff hydrographs, it is observed that the calculated runoff hydrographs by these models have good fitness with observed runoff hydrographs in outlet of watershed. Finally, these models can simulate the shape of flood hydrograph suitability and they present respond of watershed to storm events correctly. 
Evaluation of Synthetic Outlet.....

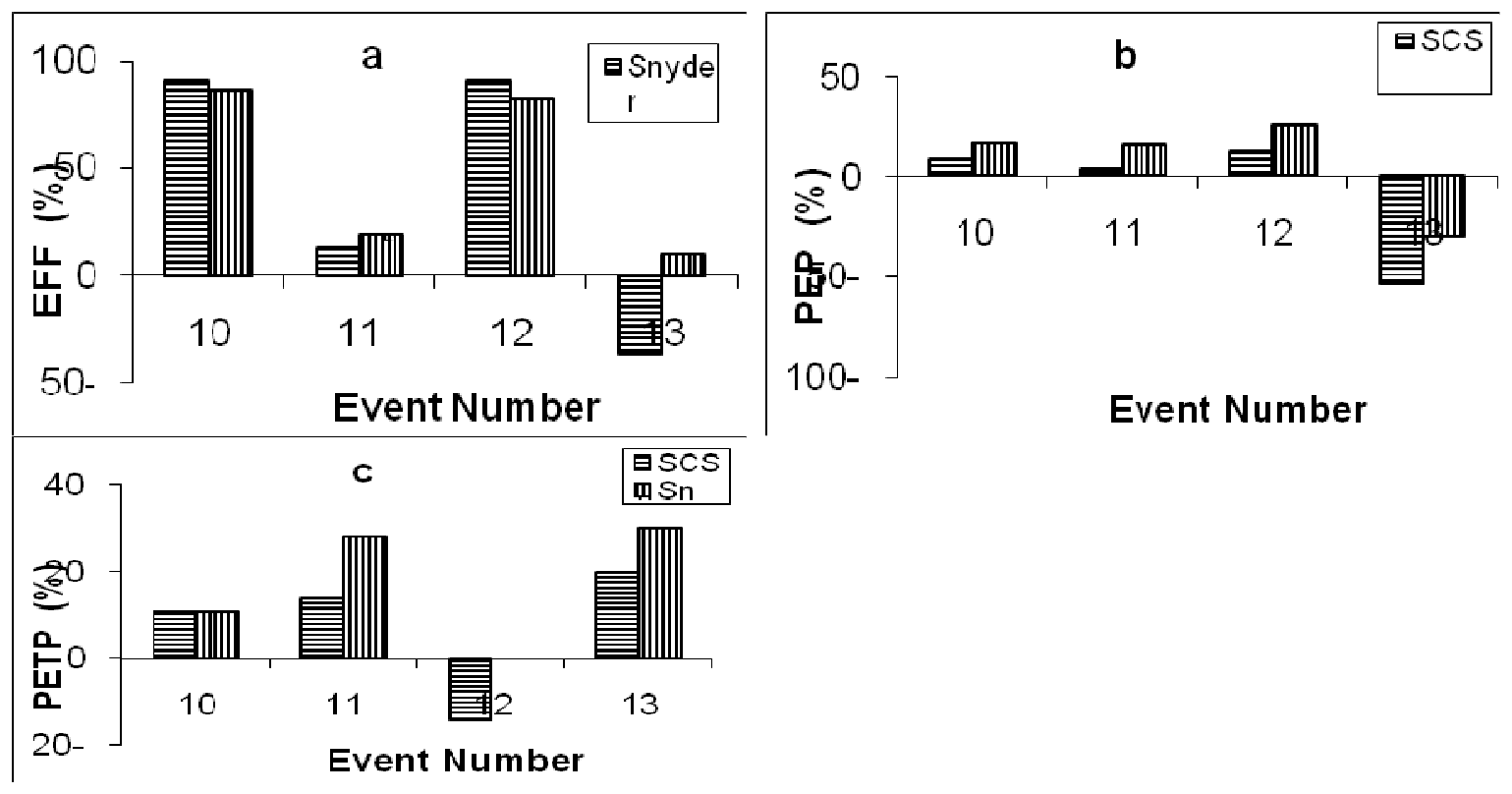

Fig.6. (a) Model efficiency EFF (b) Percentage error in peak PEP (c) Percentage error in time to peak PETP of the SCS and Snyder UH models for events $10,11,12$ and 13

\section{REFERENCES}

Bonta, J V, Roa, R A (1992). Estimating peak flows from small agricultural watersheds. Journal of Irrigation and Drainage Engineering, ASCE 118(1): 122-137.

Ghioto, R D (1991). Runoff hydrograph computation methods. A Paper for Storm Water Management.

Michel, C, Andréassian, V, Perrin, C (2005). Soil conservation service curve number method: How to mend a wrong soil moisture accounting procedure? Water Resources Research 41: 1-6 W02011.

Mishra, S K, Sahu, R K, Eldho, T I, Jain, M K (2006). An improved $I_{\mathrm{a}}-S$ relation incorporating antecedent moisture in SCS-CN methodology. Water Resources Management 20 (5): 643-660.

Mishra, S K, V.P. Singh, V P (2002). SCS-CN-based hydrologic simulation package. In: V.P. Singh and D.K. Frevert, Editors, Mathematical Models in Small Watershed Hydrology and Applications, Water Resources Publications, Littleton, Colorado (2002), 391-464.
Ponce, V M, Hawkins, R H (1996). Runoff curve number: Has it reached maturity? Journal of Hydrologic Engineering, ASCE 1(1): 11-19.

Sahu, R K, Mishra, S K, Eldho, T I, Jain, M K (2007). An advanced soil moisture accounting procedure for SCS curve number method. Hydrological Processes 21(21): 2872-2881.

Schneider, L E, McCuen, R H (2005). Statistical guidelines for curve number generation. Journal of Irrigation and Drainage Engineering, ASCE 131(3): 282-290.

SCS, (1993). Hydrology. National Engineering Handbook. Supplement A, Section 4, Chapter 10, Soil Conservation Service. USDA, Washington, DC. 